\title{
Anthropometric profile, physical activity level, degree of anxiety, and posture in college students
}

\author{
Perfil antropométrico, nível de atividade física, grau de ansiedade e postura em universitários \\ Perfl antropométrico, nivel de actividad física, grado de ansiedad y postura en estudiantes \\ universitarios

\begin{abstract}
Deborah Cristina Gonçalves Luiz Fernani', Giovana Mendes Cortez', Isabelle Amaral Santos ${ }^{1}$, Francis Lopes Pacagnelli', Thais Massetti², Talita Dias da Silva ${ }^{3}$, Denise Cardoso Ribeiro Papa², Íbis Ariana Peña de Moraes ${ }^{4}$, Carlos Bandeira de Mello Monteiro 5 , Maria Tereza Artero Prado ${ }^{6}$
\end{abstract}

\begin{abstract}
The objective of this study was to evaluate the anthropometric profile, level of physical activity, anxiety level, and posture of graduate students in the health field. This is a cross-sectional study involving 100 college students from health courses at a university in the western state of São Paulo. Weight, height, waist circumference, and body mass index data were collected. We also applied the International Physical Activity Questionnaire for physical activity; the State-Trait Anxiety Inventory for anxiety; and the Postural Assessment Instrument for postural defects. The results of this study show that $67 \%$ of students have an average BMI of $22.12 \pm 4.84 \mathrm{~kg} / \mathrm{m}^{2}$, and $38 \%$ are regularly active. Regarding anxiety levels, the sample obtained (mean STAI E 40.6 points and STAI T 40.05) can be classified as moderate. In addition, 50\% of the sample have lumbar concavity. Therefore, most health care university students displayed normal anthropometric values, were regularly active, had a moderate level of anxiety and had no postural defects.
\end{abstract}

Keywords | Anxiety; Posture; Physical Fitness.

RESUMO | O objetivo deste estudo é avaliar o perfil antropométrico, o nível de atividade física e a postura em universitários da área da saúde. Esteé um estudo transversal envolvendo 100 estudantes de uma universidade na Zona
Oeste de São Paulo. Peso, altura, circunferência da cintura e índice de massa corporal foram coletados. Também foram aplicados o Questionário Internacional de Atividade Física, o Inventário de Ansiedade Traço-Estado e o Instrumento de Avaliação Postural. Os resultados deste estudo mostram que 67\% dos estudantes têm IMC médio de 22,12ะ4,84 kg/ $\mathrm{m}^{2}$ e $38 \%$ são regularmente ativos. Acerca dos níveis de ansiedade, a amostra obtida (média IDATE E 40,6 pontos e IDATE T 40,05) pode ser classificada como moderada. Além disso, 50\% da amostra tem concavidade lombar. Portanto, a maioria dos estudantes demonstrou valores antropométricos normais, eram regularmente ativos, tinham nível moderado de ansiedade e nenhum defeito na postura corporal.

Descritores I Ansiedade; Postura; Condicionamento Físico.

RESUMEN | El objectivo de este estudio fue evaluar perfil antropométrico, nivel de actividad física, grado de ansiedad y postura de estudiantes universitarios de la salud. Este es un estudio transversal de observación envolviendo 100 estudiantes universitarios de cursos de la salud en una universidad del Oeste del estado de São Paulo, Brasil. Datos como peso, altura, circunferencia de la cintura y índice de masa corporal (IMC) fueron recogidos. Nosotros también

\footnotetext{
Study carried out at Universidade do Oeste Paulista - Presidente Prudente (SP), Brazil.

'Faculdade de Ciências da Saúde, Universidade do Oeste Paulista (Unoeste) - São Paulo (SP), Brazil.

${ }^{2}$ Graduate Program in Rehabilitation Sciences, Faculdade de Medicina da Universidade de São Paulo (FMUSP) - São Paulo (SP), Brazil. ${ }^{3}$ Graduate Program in Cardiology, Escola Paulista de Medicina (Unifesp), Universidade Federal de São Paulo - São Paulo (SP), Brazil. ${ }^{4}$ Graduate Program in Physical Activity Sciences, Escola de Artes, Ciências and Humanidades, Universidade de São Paulo (EACH-USP) São Paulo, SP, Brazil.

${ }^{5}$ Graduate Program in Rehabilitation Sciences, Faculdade de Medicina da Universidade de São Paulo (FMUSP); Graduate Program in Cardiology, Escola Paulista de Medicina (Unifesp), Universidade Federal de São Paulo; Graduate Program in Physical Activity Sciences, Escola de Artes, Ciências and Humanidades, Universidade de São Paulo (EACH-USP) - São Paulo (SP), Brazil.

${ }^{6}$ Faculdade de Ciências da Saúde, Universidade do Oeste Paulista (Unoeste) - Presidente Prudente (SP), Brazil.
} 
aplicamos el Cuestionario Internacional de Actividad Física para actividad física; el Inventario de Ansiedad Trazo-Estado (Idate) para ansiedad; y el Instrumento de Evaluación Postural para defectos de postura. Los resultados de este estudio mostraron que $67 \%$ de los estudiantes tienen IMC medio de $22.12 \pm 4.84 \mathrm{~kg} / \mathrm{m}^{2}$ y 38\% son regularmente activos. Considerándose los grados de ansiedad, el ejemplo obtenido (Idate-E de 40,6 puntos y Idate-T de 40,05) puede ser clasificado como moderado. Además, 50\% de los estudiantes del ejemplo presenta concavidad lumbar. Por lo tanto, la mayoría de los estudiantes de la salud analizados presentan valores antropométricos normales, son regularmente activos, tienen grado moderado de ansiedad y no presentan defectos posturales

Palabras clave | Ansiedad; Postura; Aptitud Física.

\section{INTRODUCTION}

New challenges arise when one starts college. It is a time of transition, which requires adaptation to this new lifestyle. This new phase may arouse fears, insecurities, uncertainties, and anxiety ${ }^{1}$.

Anxiety is an emotional state experienced by many people and can be triggered by tension caused by a stressful and physically exhausting experience; this is often the case when starting university life as the student does not know how they will adapt to this new lifestyle and have to take responsibility for themselves. However, that can be relieved by the practice of physical activity ${ }^{2,3}$.

Anxiety combined with inadequate physical activity tends to worsen the painful condition, which can trigger a vicious cycle of adversely affected posture in university students ${ }^{4}$.

When the individual starts this cycle, the state of stress excessively increases muscle contraction; the muscle cannot generate adequate relaxation, causing fatigue. Fatigue is a power outage caused by maintenance or strength failure during repeated muscle contractions. This makes it difficult to maintain a stance ${ }^{5}$. This position can be defined as body position and attitude, the relative arrangement of various body parts in order to maintain balance and harmony ${ }^{6}$.

Therefore, this study is justified because it seeks to demonstrate the level of anxiety, bad postural habits, and level of physical activity in college students attending undergraduate courses in the health area and consider if these conditions are related. This relationship could be important to clarify if physical activity can positively modify bad postural habits and anxiety levels ${ }^{7,8}$.

The objective of this research was to evaluate the anthropometric profile, level of physical activity, anxiety level, and posture of undergraduate students in the health field.

\section{METHODOLOGY}

This is a cross-sectional study involving 100 college students with an average age of $19.38 \pm 1.71$ years, enrolled in courses in the health field at a university in the western state of São Paulo. The study was approved by the Research Ethics Committee with the number CAAE: 32315314.0.0000.5515.

The proposal was presented to the coordinators of the courses in order to seek support and dissemination throughout the healthcare department; the chosen courses were Dentistry, Physical therapy, Medicine, Biomedicine, Pharmacy, and Nutrition, which are all full-time courses. Consequently, following the dissemination of information, students interested in participating were asked to enroll in the Physical Therapy Clinic for one week, being selected in the order. Enrolled students were included in the study once they agreed to sign the informed consent form. Subjects diagnosed previously with postural changes or other pathological disorders of the musculoskeletal system were excluded.

Data collection began with the identification of the individuals (name, sex, age) and anthropometric data (weight, height, waist circumference, and body mass index (BMI) ${ }^{9}$. Weight was obtained using a Plena ${ }^{\circledR}$ digital scale with a maximum capacity of $160 \mathrm{~kg}$ and a resolution of $100 \mathrm{~g}$. Each student was dressed in gym clothes (shorts and shirt) and positioned standing in the center of the scale platform, barefoot, and with arms positioned straight along the body.

Height was measured in meters (m) using a tape with a resolution of $0.1 \mathrm{~m}$, which was fixed on a smooth wall. The individual was placed in orthostatic position, barefoot, and feet together with the occiput, shoulder girdle, pelvic girdle, and the back of the heel region in contact with the wall and the head remaining in the Frankfurt horizontal plane. 
The abdominal circumference (AC) was measured in centimeters $(\mathrm{cm})$, using a tape measure with a resolution of $0.1 \mathrm{~cm}$, positioned on the umbilicus of the individual and parallel to the ground and, for this analysis, the individual was placed in the standing position, with feet together and a relaxed abdomen and arms along the body ${ }^{10}$.

The abdominal circumference is considered obese when measuring $\geq 94 \mathrm{~cm}$ in men and $\geq 80 \mathrm{~cm}$ in women, increasing the risk of metabolic complications. Already at risk of metabolic complications increased substantially $\geq 102$ for men and $\geq 88$ for women. BMI was classified as < 18.5 - underweight; 18.5 to 24.9 - normal weight; 25.0 to 29.9 - overweight; 30.0 to 34.9 - obesity I; 35.0 to 39.9 - obesity II; $\geq 40.0$ - obesity III ${ }^{11}$.

To assess the level of physical activity, the International Physical Activity Questionnaire - the 8-question short version (IPAQ) proposed by the World Health Organization (1998) - was applied ${ }^{12}$. The IPAQ consists of three levels:

- Very active: one who fulfills the criteria of vigorous activity $\geq 5$ days/week and $\geq 30$ minutes per session, or vigorous activity $\geq 3$ days/week and $\geq 20$ minutes per session + moderate exercise or walking $\geq 5$ days/week and $\geq 30$ minutes per session;

- Active: one who fulfills the criteria of vigorous activity $\geq 3$ days/week and $\geq 20$ minutes per session; or moderate exercise or walking $\geq 5$ days/ week and $\geq 30$ minutes per session; or any added activity $\geq 5$ days/week and $\geq 150$ minutes/week (walk + moderate + vigorous);

- Irregularly active: one who performs physical activity insufficiently to be classified as active as the activity does not meet the recommendations regarding frequency or duration. The accomplishment of this rating adds to the frequency and duration of different types of activities (walking + moderate+ vigorous);

- Sedentary: one who does not carry out any physical activity for at least 10 continuous minutes during the week.

This Questionnaire was self-administered.

Anxiety was assessed by the State-Trait Anxiety Inventory (STAI) $)^{13,14}$, developed by Spielberg, Gorsuch, and Lushene and translated and validated in Brazil by Biaggio and Natalicio. IDATE is a self-assessment questionnaire and consists of two parts; each has 20 questions. The first part was evaluated as follows: exceedingly anxious (4), a lot anxious (3), a bit anxious (2), and not at all anxious (1). The second part was evaluated as follows: always (4), often (3) sometimes (2) and rarely (1). Anxiety levels were scored as follows: low anxiety (20-34 points), moderate (35-49 points), high (50-64 points) and very high (65-80 points) $)^{15,16}$.

For an analysis of posture, the Instrumento de Avaliação Postural (IAP) by Liposcki ${ }^{16}$ was used, and this study used only those items pertaining to the alignment of head, shoulders and trunk ${ }^{16}$, relating to the posture symmetry impairment and affected by anxiety and stress ${ }^{17}$.

For statistical analysis, continuous data is presented as mean and standard deviation and. for categorical data, the results are presented in frequency and percentage. SPSS 15.0 was used, and the distribution of the data was assessed by the Shapiro-Wilk test. To analyze the association between the categorical data, we used the chi-square test. To evaluate the relationship between categorical and numerical data, the Spearman correlation test was used; for the relationship between numerical data, we used the Pearson test for parametric data and Spearman test for nonparametric data. The correlation magnitude parameters were recorded using those given by Portney and Watkins: from 0.00 to 0.25 , little or no correlation; $>0.25$ to 0.50 , reasonable correlation; $>0.50$ to 0.75 , moderate correlation to good; $>0.75$, good correlation to excellent; and 1.00, perfect correlation. The significance level for all tests was $5 \%$.

\section{RESULTS}

Table 1 shows the evaluation findings that characterize the sample of individuals. The anthropometric profile of the students is represented as mean and standard deviation, and the measurement of body weight was $62.05 \pm 12.91 \mathrm{~kg}$, the height was $1.65 \pm 0.08 \mathrm{~cm}, \mathrm{CA}$ was $77 \pm 9.45 \mathrm{~cm}$, and BMI was $22.12 \pm 4.84 \mathrm{~kg} / \mathrm{m}^{2}$. According to the BMI classification, $9 \%$ of the sample had low weight, $67 \%$ normal weight, $20 \%$ overweight, $2 \%$ obesity I, $1 \%$ obesity II, and $1 \%$ obesity III. Regarding the results of the IPAQ, 20\% of subjects were classified as sedentary, $38 \%$ as irregularly active, $17 \%$ as active and $25 \%$ as very active. 
Table 1. General characteristics of health care students

\begin{tabular}{|c|c|c|}
\hline General characteristics & $\mathrm{N}(\%)$ & $p$-value \\
\hline Sex & & $<0.0001$ \\
\hline Female & $82(82)$ & \\
\hline Male & $18(18)$ & \\
\hline Body mass index (BMI) & & $<0.0001$ \\
\hline Under weight & $9(9)$ & \\
\hline Normal weight & $67(67)$ & \\
\hline Overweight & $20(20)$ & \\
\hline Obesity I & $2(2)$ & \\
\hline Obesity II & $1(1)$ & \\
\hline Obesity III & $1(1)$ & \\
\hline IPAQ (classification) & & 0.016 \\
\hline Sedentary & $20(20)$ & \\
\hline Irregularly active & $38(38)$ & \\
\hline Active & $17(17)$ & \\
\hline Very active & $25(25)$ & \\
\hline IDATE trait (classification) & & $<0.0001$ \\
\hline Low & $30(30)$ & \\
\hline Moderate & $55(55)$ & \\
\hline High & $15(15)$ & \\
\hline IDATE state (classification) & & $<0,0001$ \\
\hline Low & $23(23)$ & \\
\hline Moderate & $63(63)$ & \\
\hline High & $12(12)$ & \\
\hline Very high & $2(2)$ & \\
\hline IPA (classification) & & $<0.0001$ \\
\hline Without changes & $46(46)$ & \\
\hline Lumbar concavity & $50(50)$ & \\
\hline Lumbar rectification & $4(4)$ & \\
\hline
\end{tabular}

Chi-square univariate test

Regarding the STAI findings, the sample mean score reached by IDATE 40.6 points and IDATE $\mathrm{T} 40.05$ and is classified as moderate anxiety. When considering the association between the BMI classification and the evaluation of the IAP, it was observed that there was little difference compared with normal weight individuals with concavity (32\%) and no change with normal weight (33\%). Regarding overweight individuals, 10\% of them had concavity, $8 \%$ had no change, and $2 \%$ had rectified lordosis. As for the classification of obesity (I, II, III) there was a total of $4 \%$ of individuals with concavity who were distributed across obesity II and III (2\%) and obesity I (2\%; $\mathrm{p}=0.641)$.

By linking the IPAQ test evaluation IAP, a good to excellent correlation ( $r=0.816)$ was found, which demonstrates that the concavity had a higher incidence in irregularly active individuals.
Table 2. Distribution between IPAQ test and evaluation IAP

$\begin{array}{lccccc} & \text { Sedentary } & \begin{array}{c}\text { Regular } \\ \text { active }\end{array} & \text { Active } & \text { Very active } & \text { Total } \\ \text { Hiperlordosis } & 12 & 18 & 8 & 12 & 50 \\ \text { Rectified } & 0 & 1 & 1 & 2 & 46 \\ \text { Without changes } & 8 & 19 & 8 & 12 & 4 \\ \text { Total } & 20 & 38 & 12 & 25 & 100\end{array}$

When combining IDATE with the IPAQ, the highest rate found was a moderate rating of $63 \%$, of which $23 \%$ are irregularly active, $15 \%$ active, $13 \%$ very active, and $12 \%$ inactive. In relation to the lower rate of anxiety, we found 5\% to be sedentary, $8 \%$ irregularly active, $2 \%$ active, and $8 \%$ very active; a total of $23 \%$. Of those with a high score in IDATE, 3\% were sedentary, $5 \%$ were irregularly active, no students were active, and $4 \%$ were very active, totaling $12 \%$. For very high ratings of $2 \%$, the same number was regularly active $(\mathrm{p}=0.350)$.

When the IDATE $T$ was combined with the level of physical activity, it was shown that $55 \%$ had a moderate index of anxiety, $15 \%$ were sedentary, $20 \%$ irregularly active, $10 \%$ active, and $10 \%$ very active. In the low index rating, $4 \%$ were sedentary, $10 \%$ irregularly active, $4 \%$ active, and $12 \%$ very active, totaling $30 \%$. In the high anxiety index, $1 \%$ of the population was sedentary, $8 \%$ irregularly active, $3 \%$ active, and $3 \%$ very active, totaling $15 \%(\mathrm{p}=0.183$ ).

Associating sex and the findings of IAP, $50 \%$ of the students showed concavity, with a higher incidence in women $(\mathrm{p}=0.042)$. One can justify this high incidence of concavity for individuals without change and link this to the fact that the average number of hours they spent sitting during the day was $8.31 \pm 4.33$ hours, because of the full college schedule.

Regarding the profile of anxiety and depression, there was a significant difference between the sexes in respect to STAI traits $(\mathrm{p}=0.001)$, in which $51(62.2 \%)$ women were moderate when compared with men; only $4(22,2 \%)$ women had moderate anxiety and depression. In relation to the level of physical activity, no significant difference was found between genders $(\mathrm{p}=0.024)$, in which $36(43.9 \%)$ women were regularly active and only $6(33.3 \%)$ men were active.

By analyzing the changes in the postural health of students, we observed associations with BMI classification $(\mathrm{p}=0.641)$ IPAQ $(\mathrm{p}=0.816)$, IDATE $\mathrm{T} \quad(\mathrm{p}=0.347)$, and STAI E $(p=0.720)$. Thus, postural changes were significantly correlated only with time students $(r=0.211$; $\mathrm{p}=0.034$ ), which indicates that the higher the value, the more likely the individual is to present postural changes. 


\section{DISCUSSION}

The results of this study demonstrate the anthropometric profile of health care students, with $67 \%$ of college students with normal weight and $20 \%$ overweight, according to the BMI classification. The results of the IDATE showed a higher prevalence of moderate levels of anxiety in both tests ( $T$ and $D)$, according to the classification. The level of physical activity showed that $20 \%$ of the subjects were sedentary and $38 \%$ were regularly active. The highest prevalence of postural changes $(50 \%)$ was concavity.

The IPAQ found that the highest prevalence was in irregularly active individuals (38\%), perhaps because the health benefits and improved quality of life with regular physical activity are well-known ${ }^{12}$.

However, recent evidence suggests that gender differences exist in correlations of physical activity in adolescents16. Ceschini and Júnior ${ }^{18}$ compared the level of physical activity according to sex among young people in the metropolitan region of São Paulo. The highest prevalence was regularly active individuals (44.03\%); when categorized by sex, $45.1 \%$ of women were physically active.

Female adolescents are often described as being physically less active than their male counterparts ${ }^{19,20}$.

As for this study, the IDATE showed that a moderate level of anxiety was found for both ratings (average STAI E 40.6 points and IDATE T 40.05), which resembles the study by Almondes and Araujo ${ }^{21}$, who evaluated anxiety and obtained an average of 37.9 for anxiety state and 38.84 for trait anxiety. The explanations for these findings may be due to the new phase that these students are experiencing and to the imposition of a new lifestyle.

In a study using analysis of computed photogrammetry, concavity was presented in $65.7 \%$ of university students ${ }^{22}$, which is similar to the findings of this study in which concavity was the postural change with the highest incidence: $50 \%$ of college students with a prevalence in women (45\%). This fact is reinforced in the study by Baroni et al. ${ }^{23}$, which also shows a higher prevalence of concavity in female students and active individuals. The justification for this prevalence in women may be explained by the female anatomy and the presence of anteversion, which is associated with the shortening of the quadratus lumborum, psoas ilium, and adductors. All this postural change may result in pressure overload on the lower back, which can develop into other musculoskeletal disorders.
In this study, $20 \%$ of students were overweight and $67 \%$ were normal weight, which is similar to the study by Miranda et al..$^{24}$, which evaluated 685 college students and found the prevalence of overweight to be $16 \%$ and the study of Miranda et al. ${ }^{25}$, which evaluated 535 students and verified $18.3 \%$ as overweight and obese and $75.2 \%$ as normal weight ${ }^{24}$. Although there is a prevalence in the category of normal weight, what stands out are those with excess weight, as obesity is a risk factor for the development of psychosocial disorders, cardiovascular diseases, endocrine disorders, sleep disorders, and more advanced age obesity ${ }^{26}$.

By associating the level of anxiety with the practice of exercise, it was shown that $63 \%$ of students were classified as having a moderate level of anxiety and 51\% engaged in some kind of physical activity. The study by Cevada et al. ${ }^{3}$ related sport to anxiety, quality of life, and resilience and it acknowledges that athletes and former athletes are less anxious than sedentary people. This fact shows that physical activity contributes to the physical and emotional well-being.

As already discussed, when relating anxiety level to physical exercise, we found that regardless of the level of anxiety, young people respond similarly to exercises of different intensities with a decreased level of anxiety, which affects physical and associated emotional well-being ${ }^{25}$.

When correlated with BMI, IDATE shows that having a lower body mass index can provide a higher level of anxiety. A study by Rocha reported no association between high BMI and a high level of anxiety in an individual ${ }^{27}$. A study by Hainzenreder et al. ${ }^{28}$ evaluated this on 136 students of a Physical Education course; their study found $\mathrm{AC}$ with an average of $77.1 \pm 0.62 \mathrm{~cm}$, which is similar to the average $\mathrm{AC}$ found on this study of $77 \pm 9.45 \mathrm{~cm}$, with no difference between the sexes.

In relation to time spent sitting, the average time was 6 hours, justifying the lack of time - especially taking into account internships and other activities - for physical activity. In the current study, this means that college students spent $8.31 \pm 4.33$ hours sitting, which is a figure similar to that found in the work done by Raddi et al. ${ }^{29}$ which evaluated 186 third year students at the Faculdade de Ciências Médicas da Santa Casa de São Paulo and their level of physical activity; the accumulation of time sitting averaged $8.92 \pm 8.72$ hours on weekdays.

As estimated by Farias et al. ${ }^{30}$, this study shows that: 98\% of subjects had no side nods, $94 \%$ had no forward or back head projection, $75 \%$ had no shoulder elevation, 
$83 \%$ had no protruding shoulder, $64 \%$ had symmetrical Tales Triangle (formed between the shoulders, upper limbs and spine), $97 \%$ had no trunk rotation, $90 \%$ had no cervical abnormalities, $94 \%$ had no chest changes, 98\% had no changes in the shoulder blade, and 94\% did not have scoliosis. Fifty percent had concavity; the higher incidence of concavity was in women, suggesting a weakness of the abdominal muscles, which has a higher prevalence in women and can contribute to this postural change.

These findings are different when compared with studies of teenage dance practitioners, which give a higher percentage of postural changes; $100 \%$ of the adolescents had shoulder elevation on the left or right, $50 \%$ had anterior shoulders, $50 \%$ had normal shoulders, $80 \%$ had a higher Tales Triangle to the right and $20 \%$ had it higher to the left, $80 \%$ had trunk rotation or inclination, with a predominance of rotation to the right compared with the profile of the umbilicus, 50\% had asymmetry towards the left, $60 \%$ had no cervical abnormalities, $80 \%$ had no chest changes, $80 \%$ had scoliosis in the cervical, thoracic, or lumbar region, and $80 \%$ of adolescents had lumbar concavity ${ }^{30}$.

\section{CONCLUSION}

The anthropometric profiles of university health care students are within normal standards. These students are regularly active and the practice of physical activity softens anxiety symptoms, which are stratified at a moderate level. Alterations are present in this population and lumbar concavity has a higher incidence than the standard, especially in women. There is a need for further studies with research approaches directed at other elements and intervention in the university population, who can be particularly vulnerable to anxiety when not practicing physical activity.

\section{REFERENCES}

1. Bassols AM, Sordi AO, Eizirik CL, Seeger GM, Rodrigues GS, Reche M. A prevalência de estresse em uma amostra de estudantes do curso de medicina da Universidade Federal do Rio Grande do Sul. Rev HCPA. 2008;28(3):153-7.

2. Gama MMA, Moura GS, Araújo RF, Teixeira-Silva F. Ansiedadetraço em estudantes universitários de Aracaju (SE). Rev Psiquiatr Rio Gd Sul. 2008;30(1):19-24. doi: 10.1590/ S0101-81082008000100007
3. Cevada T, Cerqueira LS, Moraes HSd, Santos TMd, Pompeu FAMS, Deslandes AC. Relação entre esporte, resiliência, qualidade de vida e ansiedade. Rev Psiquiatr Clin. 2012;39(3):85-9. doi: 10.1590/S0101-60832012000300003

4. Farah BQ, Barros MVG, Farias Júnior JC, Ritti-Dias RM, Lima RA, Barbosa JPAS, et al. Percepção de estresse: associação com a prática de atividades físicas no lazer e comportamentos sedentários em trabalhadores da indústria. Rev Bras Educ Fís Esporte. 2013;27(2):225-34. doi: 10.1590/ S1807-55092013000200007

5. Cheik NC, Reis IT, Heredia RAG, Ventura MdL, Tufik S, Antunes HKM, et al. Efeitos do exercício físico e da atividade física na depressão e ansiedade em indivíduos idosos. Rev Bras Ciênc Mov. 2003;11(3):45-52.

6. Costa TB, Giantorno JB, Suzuki FS, Oliveira DL. Análise postural em escolares do ensino fundamental. Rev Bras Ciênc Saúde. 2012;16(2):219-22. doi: 10.4034/RBCS.2012.16.02.14

7. Freitas ECG, Ferreira EAG. Alinhamento postural, ansiedade e estresse em adultos jovens. Rev PIBIC. 2007;4(1):81-94.

8. Sloan RA, Sawada SS, Girdano D, Liu YT, Biddle SJH, Blair SN. Associations of sedentary behavior and physical activity with psychological distress: a cross-sectional study from Singapore. BMC Public Health. 2013;13(1):885. doi:10.1186/1471-2458-13-885

9. Castro TGd, Barufaldi LA, Schlüssel MM, Conde WL, Leite MS, Schuch I. Waist circumference and waist circumference to height ratios of Kaingáng indigenous adolescents from the State of Rio Grande do Sul, Brazil. Cad Saúde Pública. 2012:28(11):2053-62. doi: 10.1590/S0102-311X2012001100005

10. Cabrera TFC, Correia IFL, Santos DO, Pacagnelli FL, Prado MTA, Silva TD, et al. Analisys of the prevalence of overweight and obesity and the level of physical activity in children and adolescents of a southwestern city of São Paulo. J Human Growth Develop. 2014;24(1):67-72.

11. Bener A, Yousafzai MT, Darwish S, Al-Hamaq AOAA, Nasralla EA, Abdul-Ghani M. Obesity index that better predict metabolic syndrome: body mass index, waist circumference, waist hip ratio, or waist height ratio. J Obesity. 2013; 2013: 269038. doi: 10.1155/2013/269038

12. Pardini R, Matsudo S, Araújo T, Matsudo V, Andrade E, Braggion $G$, et al. Validação do questionário internacional de nível de atividade física (IPAQ-versão 6): estudo piloto em adultos jovens brasileiros. Rev Bras Ciên e Mov Brasília. 2001;9(3):39-44.

13. Spielberger CD, Gorsuch RL, Lushene R, Vagg PR, Jacobs GA. Manual for the state-trait anxiety inventory. J Clin Psychiatry. 1983:53:267-71.

14. Biaggio AMB, Natalício L. Manual para o inventário de ansiedade traço-estado (IDATE). CEPA. 1979;15.

15. Leal RA, dos Santos ALM, da Silva CA, Borges RGL, Barbosa ANO. Depression and anxiety traits among medical students. Rev Paraense Med. 2010;24(2):13.

16. Liposcki DB, Rosa Neto F, Savall AC. Validação do conteúdo do instrumento de avaliação postural-IAP. Rev Digital. 2007;12(109):1-7.

17. Lipnicki DM, Byrne DG. An effect of posture on anticipatory anxiety. Int J Neuroscience, 2008;118:227-37. doi: 10.1080/00207450701750463 
18. Ceschini FL, Júnior AF. Physical activity level in young adults living at the metropolitan region of São Paulo. Rev Atenção Saúde. 2010;4(8).

19. Oehlschlaeger MHK, Pinheiro RT, Horta B, Gelatti C, San'Tana P. Prevalência e fatores associados ao sedentarismo em adolescentes de área urbana. Rev Saúde Pública. 2004;38(2):157-63. doi:10.1590/S0034-89102004000200002

20. Coelho JJ, Graciosa MD, De Medeiros DL, Da Costa LMR, Martinello M, Ries LGK. Influência do perfil nutricional e da atividade física na postura de crianças e adolescentes. Fisioter Pesqui. 2013;20(2):136-42. doi: 10.1590/ S1809-29502013000200007

21. Almondes KM, Araújo JF. Padrão do ciclo sonovigília e sua relação com a ansiedade em estudantes universitários. Estud Psicol. 2003;8(1):37-43. Doi: 10.1590/ S1413-294X2003000100005

22. Santos AMCD, Amaral CP, Oliveira MRTO, Souza Bastos VC, Nascimento LSG, Cunha EF, et al. Alterações posturais da coluna vertebral em indivíduos jovens universitários: análise por biofotogrametria computadorizada. Saúde Pesqui. 2014;7(2):191-8.

23. Baroni BM, Bruscatto CA, Rech RR, Trentin L, Brum LR. Prevalência de alterações posturais em praticantes de musculação. Fisioter Mov. 2010;23(1):129-39. doi: 10.1590/ S0103-51502010000100013
24. Miranda VPN, Filgueiras JF, Neves CM, Teixeira PC, Ferreira MEC. Insatisfação corporal em universitários de diferentes áreas de conhecimento. J Bras Psiquiatr. 2012;61(1):25-32.

25. Miranda R, Neto ES, De Mello M, Antunes H. O nível de ansiedade traço influencia a percepção de fadiga e bem-estar após diferentes intensidades de exercício físico? Rev Bras Ativ Fís Saúde. 2014;18(6):730. doi: 10.12820/RBAFS.V.18N6P730

26. Speiser PW, Rudolf MCJ, Anhalt H, Camacho-Hubner C, Chiarelli F, Eliakim A, et al. Childhood obesity. J Clin Endocrinol Metab. 2005;90(3):1871-87. doi: 10.1210/jc.2004-1389

27. Rocha C, Costa E. Aspectos psicológicos na obesidade mórbida: avaliação dos níveis de ansiedade, depressão e do auto-conceito em obesos que vão ser submetidos à cirurgia bariátrica. Aná Psicol. 2012;30(4):451-66.

28. Hainzenreder ID, Montes LS, Schwengber LM, Lopes CP. Tempo habitual de atividade física de universitários durante as fases do curso de educação física na cidade de Torres-RS. RBPFEX- Rev Bras Prescr Fisiol Exerc. 2012;4(22):409-20.

29. Raddi LLdO, Silva Júnior JPd, Ferrari GLdM, Oliveira LCd, Matsudo VKR. Physical activity level and accumulation of sitting time among medical students. Rev Bras Med Esporte. 2014;20(2):101-4.

30. Farias AR, Berria J, Daronco LSE, Balsan LAG. Avaliação postural, aptidão física relacionada à saúde e avaliação da imagem corporal de adolescentes praticantes de dança: um estudo de caso. Rev Uniabeu. 2012;5(10):115-26. 